(Rzym)

\title{
PRÓBA REKONSTRUKCJI DOKTRYNY I STRUKTURY KOŚCIOŁA NOWACJAŃSKIEGO
}

W artykule tym podejmuję próbę rekonstrukcji doktryny oraz struktur, które ukształtowały się w Kościele nowacjańskim. Rekonstrukcja ta będzie przebiegała następującymi etapami: w pierwszym zostanie zaprezentowana praktyka pokutna Kościoła nowacjańskiego na tle przemian katolickiej dyscypliny pokutnej, w drugim zostanie przedstawiony wpływ Nowacjana na rzymską wspólnotę nowacjan, trzeci będzie próbą rekonstrukcji doktryny i struktury Kościoła nowacjańskiego, a czwarty będzie dotyczyć odniesienia Soboru Nicejskiego do Kościoła nowacjańskiego.

Podczas gdy Kościół syryjski w połowie III wieku zajmuje się kwestiami dotyczącymi przede wszystkim ascezy, a Aleksandria głównie zagadnieniami natury teologicznej, problemy chrześcijaństwa łacińskiego odnoszą się zasadniczo do organizacji Kościoła. To właśnie na Zachodzie, w Rzymie, spotykamy pierwszą wspólnotę nowacjańską, zgromadzoną wokół swego założyciela. Podjęta refleksja stanowi próbę odpowiedzi na dwa zasadnicze pytania: jaka doktryna wyznawana jest w tym Kościele i jakie są jego organizacyjne struktury.

\section{POKUTA W KOŚCIELE NOWACJAŃSKIM NA TLE PRZEMIAN KATOLICKIEJ DYSCYPLINY POKUTNEJ}

Sekta Nowacjana, powołując się wyraźnie na wcześniejszą dyscyplinę pokutną, chcąc zachować w Kościele dawną czystość, odmawiając uznania domu Bożego za arkę Noego, w której sąsiadowało ze sobą czyste i nieczyste, odnalazła swe specyficzne „miejsce” po ustaniu prześladowań. Jest to miejsce, które już wcześniej wyznaczył spór Kaliksta i Hipolita. Papież Kalikst przyjął jako jeden z pierwszych bardziej wielkoduszną postawę wobec grzechów cielesnych. W tym celu odwoływał się do przypowieści o chwaście (Mt 13, 24-30), do ironicznego pytania świętego Pawła - „Kim jesteś ty, co się odważasz sądzić cudzego sługę?” (Rz 14,4) - i właśnie do połączenia razem czystych i nieczystych zwierząt w arce Noego. Wszystko to według niego przemawiało za tym, że w Kościele powinno być miejsce dla grzeszników ${ }^{1}$.

\footnotetext{
${ }^{1}$ Por. J. Kelly, Poczatki doktryny chrześcijańskiej, thum. J. Mrukówna, Warszawa 1978, 167.
} 
Kiedy Kościół ucierpiał w prześladowaniach, pojawiły się protesty niektórych chrześcijan wobec możliwości pojednania lapsi. W tym czasie istniała bowiem w Kościele głęboko zakorzeniona doktryna, dotycząca niemożliwości przebaczenia pewnych grzechów: pod koniec II wieku cudzołóstwo, zabójstwo i bałwochwalstwo (lub apostazję) uważano w praktyce za nieodpuszczalne, nawet za pośrednictwem exomologesis ${ }^{2}$. Niektórzy badacze wysuwają wątpliwości, czy było tak wszędzie, ale dopuszczając pewne lokalne rozwiązania tej kwestii, podkreślają jednak, że w wielu ważnych ośrodkach była taka praktyka.

Hipolit, protestując przeciw nowemu rozwiązaniu zaproponowanemu przez papieża Kaliksta, a także Tertulian (w okresie montanistycznym), przyjmowali za rzecz oczywista, iż dotąd Kościół zastrzegał sobie takie właśnie grzechy. Orygenes natomiast zdaje się przekazywać stanowisko wiążące dla Wschodu: pod kierownictwem Ducha Świętego dobry biskup „odpuszcza wszelkie grzechy, które Bóg odpuszcza, ale zatrzymuje nieodpuszczalne"3. Cytuje on I Księgę Samuela (2, 25): , gdy człowiek zawini wobec Pana - któż się za nim będzie wstawiał?", klasyczny tekst w dyskusjach na temat pokuty. Dodaje jednocześnie, że bałwochwalstwo, cudzołóstwo i nierząd są tymi grzechami, na które nie ma lekarstwa ${ }^{4}$.

Wobec osłabienia starej dyscypliny przez edykt Kaliksta ${ }^{5}$, w wielu miejscach zaczął pojawiać się sprzeciw, choć nie chodzi tu tylko o jego gwałtow-

2 Por. C. Vogel, Penitenza e riconciliazione, NDPAC III 4012-4017. Od początku III wieku zaczęły się kształtować ogólne ramy powszechnie przyjętej praktyki pokutnej. System, który obowiązywał, to pokuta publiczna. Zawierała ona wyznanie grzechów, okres pokuty i wykluczenie ze społeczności, dalej formalne rozgrzeszenie, przyjęcie do wspólnoty, a cały ten proces był nazywany exomologesis, zob. Kelly, Poczatki doktryny, s. 167; szerzej: S. Czerwik, Zarys dziejów pokutnej praktyki Kościoła, w: Sakrament pokuty, red. A. Skowronek, Katowice 1980, 127-175; A. Młotek, Aktualne wartości dawnej praktyki pokutnej w Kościele, ChS 14 (1982) nr 9, 49-63; tenże, Pokuta i pojednanie w Kościele pierwotnym, CS 17 (1985), 167-184; J. Janicki, Pokuta w nauczaniu i praktyce Kościoła dwóch pierwszych wieków, „Folia Historica Cracoviensia” 3 (1996), 287-304; W. Zawadzki, Nauka o pokucie i praktyka pokutna w Kościele Rzymskim w okresie starożytności chrześcijańskiej, VoxP 10 (1990) z. 19, 807-815; B. Kosecki, Wyznanie grzechów w praktyce pokuty Kościoła na Zachodzie, RBL (1976), 65-81; C. Vogel, Le pécheur et la pénitence dans l'Église ancienne, Paris 1966; Ph. Rouillard, Historie de la pénitence des origines à nos jours, Paris 1996; R.N. Longenecker, New wine into fresh wineskins. Contextualizing the early Christian confession, Peabody 1999; J. de Mayke, Transformation of penance, w: Rituals of power, from Late Antiquity to the early Middle Ages, ed. F. Theuws - J.L. Nelson, Leiden 2000, 185-224.

${ }^{3}$ Origenes, De oratione 28, 8, GCS 3, 380, thum. W. Kania, w: Odpowiedź na stowo, red. H. Pietras, Kraków 1993, 208.

${ }^{4}$ Por. Kelly, Poczatki doktryny, s. 167; H. Pietras, Poczatki teologii Kościoła, Kraków 2000, 114.

${ }^{5}$ Postępujący rygoryzm i szerzący się montanizm wpływały na udzielanie tylko jednej pokuty po chrzcie. W odpowiedzi na zaistniałą sytuację papież Kalikst I (217-220) wydał dekret łagodzący, pozwalający na odpuszczenie grzechów ciężkich. Tertulian z oburzeniem upomina biskupa ( $D e$ pudicitia 1,6), który wydał edykt, że jest gotów udzielić rozgrzeszenia osobom, które dopuściły się cudzołóstwa czy nierządu, jeśli odbędą należną pokutę. Choć sprawa odnosiła się do Agrypina, biskupa Kartaginy, to jednak przypuszcza się, że Tertulian uderzał w samego Kaliksta. 
ność, jak to było w przypadku Tertuliana czy Hipolita ${ }^{6}$. W Afryce bowiem byli biskupi podzielający myśl Cypriana, który tak uważał:

„,nie powinno się przyznawać pokoju cudzołożnikom, trzeba całkowicie wykluczyć z pokuty tych, którzy popełnili ten grzech"’

Wydaje się, że poglądy Cypriana w tej kwestii jednak ewoluowały. W Afryce bowiem w wielu miejscach już w jego czasach uważano za normalne rozgrzeszenie udzielone po odpowiedniej pokucie tym, którzy dopuścili się grzechów ciała:

„Moechis a nobis paenitentiae tempus conceditur et pax datur"

Cyprian jest zatem świadkiem, że chociaż pewne grzechy seksualne mogły być odpuszczone, to jednak wcześniejsze spory w tej kwestii do końca nie wygasły. Potwierdza to fragment tego samego listu:

„Apud antecessores nostros quidam de episcopis istic in provinicia nostra dandam pacem moechis non putaverunt et in totum paenitentiae locum contra adulteria clauserunt"

Biskup Kartaginy dostrzegał w tym stanowisku pewną manifestację władzy biskupów:

„Manente concordie vinculo et perseverante catholicae Ecclesiae individuo sacramento, actum suum disponit et dirigit unusquisque episcopus, rationem propositi sui Domino redditurus" ${ }^{10}$.

Wydaje się, że nowe ustępstwa, które pojawiły się z powodu prześladowań, spowodowały jeszcze większy opór. Wobec rozprzestrzeniania się tendencji laksystycznej, która wydawała się im niepokojąca, wielu chrześcijan buntowało się. Te spostrzeżenia pozwalają w pewnym stopniu zrozumieć, w jaki sposób rygorystyczna i schizmatycka wspólnota nowacjan rzymskich zdobędzie w całym cesarstwie ważnych zwolenników. Nowacjan, jak zauważa Sokrates:

„pisał do wszystkich Kościołów, że nie można dopuścić do misterium tych,

${ }^{6}$ W Kościele rzymskim Hipolit oskarżył papieża Kaliksta o laksyzm. Natomiast Tertulian montanista w piśmie De pudicitia odmówił Kościołowi władzy rozgrzeszania grzechów ciężkich (mortalia), posuwając się do stwierdzenia, że nawet gdyby Kościół miał taką władzę, to nie powinien z niej korzystać, por. B. Kumor, Historia Kościoła, t. 1, Lublin 2001, 90-91; zob. także: tenże, Pokuta kościelna $w$ pismach Tertuliana, RTK 4 (1957) z. 2, 123-143; R. Andrzejewski, Pokuta w nauczaniu Ojców Kościoła, AK 69 (1977), t. 89, 33-46.

${ }^{7}$ Cyprianus, Epistula 55 (52), 21, 1, CCL 3B, 280 (przekłady tekstów, jeśli nie podano tłumacza, pochodzą od autora); por. tłum. W. Szołdrski, PSP 1, Warszawa 1969, 154.

${ }^{8}$ Tamże 55, 21, 1, CCL 3B, 279.

9 Tamże 55, 21, 1, CCL 3B, 280.

10 Tamże 55, 21, 2, CCL 3B, 280. 
którzy się wyrzekli, ale zachęcać ich do pokuty, pozostawiając Bogu kwestię wybaczenia im, bo tylko On może odpuścić grzechy"11.

Niektórzy biskupi połączyli się z Nowacjanem i uznali jego zasady. W Galii Nowacjan pozyskał Marcjana z Arles ${ }^{12}$, o którym Cyprian zaznaczył, „że przyłączył się do Nowacjana, oddalił się od prawdy Kościoła katolickiego i jedności ciała biskupiego"13. Inni, jak Fabiusz z Antiochii, wahali się ${ }^{14}$. W całokształcie jednak stanowisko biskupów ze Wschodu pozostało raczej nienaruszone. Biskupi zdawali sobie sprawę, że nowym warunkom powinna odpowiadać nowa dyscyplina pokutna. To pomiędzy zwykłymi wiernymi oraz kapłanami będącymi w konflikcie ze swoimi zwierzchnikami doktryna Nowacjana miała największe szanse sukcesu. W wielu miastach tworzyły się grupy odstępców, które zostały wkrótce wzmocnione przez obecność duchownych ${ }^{15}$. Tak było na przykład w Kartaginie, gdzie złożoność kwestii lapsi doprowadziła do utworzenia, obok Kościoła katolickiego, na którego czele stał Cyprian, Kościoła laksystów (byłe stronnictwo Felicjana z Fortunatem jako biskupem) i Kościoła nowacjańskiego ${ }^{16}$.

W jaki sposób do tego doszło? Jak już zauważono, Nowacjan wysyłał w różne strony Afryki swoich emisariuszy. Do Kartaginy posłał kapłana Maksyma, diakona Augendusa oraz świeckich Machaeusa i Longinusa ${ }^{17}$. Wysiłki te zmierzały do tego, aby pozyskać dla swoich poglądów episkopat afrykański, który na początku był im niechętny. Później Ewaryst, autor schizmatycki, jak określa go Korneliusz ${ }^{18}$ (nie oznacza to jednak, że Ewaryst był jednym z konsekratorów Nowacjana), diakon Nikostrat, Nowat, Dionizy i Primus tworzą w Kartaginie Kościół nowacjański. Wspominany już Maksym ${ }^{19}$ znalazł sposób, aby wyświęcić się na biskupa:

„Pars Novatiani, Maximum presbyterum nuper ad nos a Novatiano legatum missum atque a nostra communicatione rejectum nunc istic sibi fecisse pseudoepiscopum dicitur" ${ }^{\prime 20}$.

${ }^{11}$ Socrates, HE IV 28, PG 67, 537B.

${ }^{12}$ Por. Cyprianus, Epistula 68, 2-3; H.J. Vogt, Novatian. Novatianismus, LThK VII 939.

${ }^{13}$ Cyprianus, Epistula 68, 1, CCL 3C, 463.

${ }^{14}$ Por. J. Daniélou - H.I. Marrou, Historia Kościoła, thum. M. Tarnowska, Warszawa 1984, 161. Na Wschodzie, mimo że Nowacjan znalazł sprzymierzeńca w Fabiuszu z Antiochii, doszło do porozumienia między Aleksandrią i Antiochią, która popierała pojednanie lapsi i ostatecznie poparła Korneliusza (Eusebius, HE VI 44, 1; VI 46, 3); zob. także J.S. Alexander, Novatian, Novatianer, TRE XXIV 678-682.

${ }^{15}$ Por. É. Amann, Novatien, DThC XI/1 842.

${ }^{16}$ Por. P. Mattei, Novaziani, NDPAC II 3553.

${ }^{17}$ Por. tamże.

${ }^{18}$ Por. Cyprianus, Epistula 50, 1-2, CCL 3B, 238-239.

${ }^{19}$ Por. Mattei, Novaziani, NDPAC II 3553; R.J. DeSimone, Novatiens, w: Dictionary of Christian Antiquity (= DCA), ed. W. Smith - S. Cheetham, I, London 1876-1880, 1780.

${ }^{20}$ Cyprianus, Epistula 59, 9, 2, CCL 3C, 351. 
To co wydarzyło się w Kartaginie, mogło wydarzyć się również gdzie indziej. Nie możemy wymienić nazwać wszystkich wspólnot nowacjańskich w Afryce, ale wiemy, że wokół kwestii chrztu, udzielanego w tych wspólnotach, rozpoczął się spór na temat jego ważności. Dwa listy Cypriana do biskupów Magnusa i Jubajana kwestionują prawomocność chrztu przynależących do Kościoła Nowacjana ${ }^{21}$. Problem ważności chrztu heretyków jest podejmowany przez ówczesne synody: w Ikonium (230-235) 22 , w Synnadzie (ok. 235) ${ }^{23}$, w Kartaginie - w roku $220(\text { ? })^{24}$, jesienią $255^{25}$, wiosną $256^{26}$, ponownie w Kartaginie (1 IX 256) ${ }^{27}$, synod w Rzymie $(255 / 256)^{28}$ oraz w Iko-

${ }^{21}$ Por. Cyprianus, Epistulae 69 i 73.

${ }^{22}$ Chrzest udzielony przez heretyków jest nieważny, por. Concilium Iconicum (230-235): De invaliditate baptismi haereticorum, ŹMT 37 (SCL 1), 4.

${ }^{23}$ Jest to replika synodu w Ikonium (230-235), por. ŹMT 37 (SCL 1), 4.

${ }^{24}$ Por. Concilium Carthaginiense (ca. 220), ŹMT 37 (SCL 1), 4: „chrzest udzielony przez heretyków jest nieważny".

${ }^{25}$ Synod kartagiński z udziałem 31 biskupów podtrzymał afrykańską tradycję udzielania chrztu ludziom ochrzczonym przez heretyków, gdy chcą wrócić do Kościoła, por. Concilium Carthaginiense (255) can. 1, XMT 37 (SCL 1), 22: „Będąc wspólnie zebrani na synodzie, przeczytaliśmy wasz list, najdrożsi bracia, jaki napisaliście w sprawie tych, którzy u heretyków i schizmatyków rzekomo są ochrzczeni. Pytacie się czy tacy, wstępując do Kościoła katolickiego, który jest jeden i prawdziwy, muszą otrzymać chrzest? ...Przedstawiamy wam nasze zdanie, nie nowe, lecz już od dawna przez naszych poprzedników ustalone i przez nas zachowywane i co do tego łączymy się z wami, sądząc tak samo. Uważamy mianowicie i jesteśmy pod tym względem pewni, że poza Kościołem nikt ochrzczony być nie może. Jeden bowiem jest tylko ustanowiony chrzest (baptisma unum) w świętym Kościele”. W ramach tego synodu wypowiadali się biskupi Rzymu Stefan i Sykstus II uznający każdy chrzest, Firmilian z Kapadocji i Cyprian uznający chrzest tylko w Kościele oraz Dionizy z Aleksandrii, próbujący mediacji między obu stronami, zob. H. Pietras, Dionizy Aleksandryjski wobec sporu o ważność chrztu heretyków, RTK 36 (1989) z. 4, 103-117.

${ }^{26} \mathrm{Na}$ temat ważności chrztu heretyków, 71 biskupów obradowało ponownie wiosną 256 r., podtrzymując stanowisko z synodu z roku 255. Zabroniono też sprawować funkcje płynące ze święceń tym, którzy zostali wyświęceni przez heretyków lub też odeszli od ortodoksji, por. Concilium Carthaginiense (256) = Cyprianus, Epistula 72, 1, thum. W. Szołdrski, ŹMT 37 (SCL 1), 25: „Postanowiliśmy bowiem, że zanurzonych poza Kościołem i skalanych skazą bezbożnej wody u heretyków i schizmatyków, gdy przychodzą do nas i do Kościoła, który jest jeden, należy chrzcić i że za mało jest włożyć na nich rękę, aby otrzymali Ducha Świętego, jeśli nie otrzymają chrztu w Kościele.

${ }^{27} \mathrm{~W}$ tym kartagińskim uczestniczyło 85 biskupów (dwóch nieobecnych, w ich imieniu przemówił biskup Natalis z Oei) z całej łacińskiej Afryki. Ponownie dyskutowano kwestię ważności chrztu heretyków. Zachował się protokół z przebiegu obrad; opowiedziano się na nim za praktyką potwierdzoną na poprzednich synodach, por. Concilium Carthaginiense (256): Sententiae LXXXVII episcoporum, tłum. J. Czuj, ŹMT 37 (SCL 1), 27: „po odczytaniu listu Jubajana do Cypriana na temat chrztu heretyków, a także innego jeszcze pisma Jubajana do Cypriana, Cyprian przemówił tymi słowami: Słyszeliście, najdrożsi koledzy, co mi pisał współbiskup Jubajan, radząc się mej skromnej osoby w sprawie niedozwolonego i bezbożnego chrztu heretyków, i co ja mu odpisałem oświadczając - co już niejednokrotnie powtarzałem - że heretyków, zgłaszających się do Kościoła, należy chrzcić i uświęcać chrztem Kościoła".

${ }^{28}$ Synod rzymski zebrany pod przewodnictwem papieża Stefana orzekł, że chrzest udzielany przez heretyków pozostaje ważny i należy ich przyjmować rytem nałożenia rąk, por. Concilium Ro- 
nium (256? $)^{29}$. Jeśli powrót ludzi ochrzczonych w Kościele nowacjańskim był problemem od 255 roku to znaczy, że wspólnoty schizmatyckie szybko się rozprzestrzeniły i zorganizowały.

\section{WPŁYW NOWACJANA NA RZYMSKĄ WSPÓLNOTĘ NOWACJAŃSKĄ}

Prawdopodobnie Nowacjan, podobnie jak prawowici biskupi Rzymu, został wygnany ze stolicy w czasie prześladowań Gallusa (253), oraz później w pierwszym roku prześladowań Waleriana $(257)^{30}$. To być może te okoliczności zrodziły tradycję „męczeństwa” Nowacjana ${ }^{31}$. Późniejsze źródła utrzymują, że Nowacjan był męczennikiem za czasów Waleriana. W 1932 roku w katakumbie w pobliżu Bazyliki św. Wawrzyńca za Murami odkryto następujący napis: Novatiano beatissimo martyri Gaudentius diaconus fecit (diakon Gaudentius wykonał to dla błogosławionego męczennika Nowacjana). Jednak identyfikacja tego męczennika z założycielem sekty nie może zostać udowodniona, jest nawet raczej nieprawdopodobna ${ }^{32}$. Pisze o niej Sokrates:

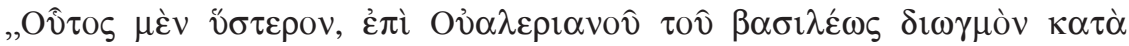

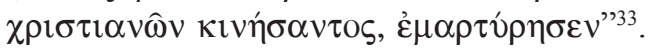

manum (255), tłum. H. Pietras, ŹMT 37 (SCL 1), 24: „Święty i boski synod prowincjalny w Rzymie, zebrany przez Stefana, świętego męczennika i papieża: odrzucił zdanie tych, którzy zebrali się na synodzie afrykańskim i bez powodu zarządzili, by ponownie chrzcić przychodzących do Kościoła katolickiego z jakiejkolwiek herezji”..

${ }^{29} \mathrm{Na}$ synodzie w Ikonium dyskutowano o chrzcie heretyków (montanistów). Papież Stefan zerwał komunię z Kościołami azjatyckimi nieuznającymi ważności chrztu heretyków, a legatów doń wysłanych w tej sprawie nie przyjął. Po synodzie bp Firmilian napisał pełen oburzenia list do Cypriana, zdając sprawę z wypadków, por. Concilium Iconicum (256), ŹMT 37 (SCL 1), 41.

${ }^{30}$ Por. Amann, Novatien, DThC XI/1 816.

${ }^{31}$ Według Sokratesa (HE IV 28), Nowacjan poniósł przypuszczalnie pod rządami Waleriana śmierć męczeńską, por. R.T. Klein, Novatian, BBKL VI 1047-1049. J. Alexander (Novatian, TRE XXIV 679) uważa natomiast, że jako jeden z najwybitniejszych chrześcijan Rzymu mógł umrzeć podczas późniejszej fazy prześladowań, najprawdopodobniej za Waleriana w 258 r., jeżeli nie został stracony na wygnaniu. W każdym razie jego przeciwnicy odmawiali mu tytułu męczennika, którego z kolei domagali się później jego zwolennicy, zob. Pacianus, Epistula 2, 7, PL 13, 1062-1063; Socrates HE IV 28; Eulogius, Fragmenta, PG 86/2, 2937-2964, lub ich streszczenia w: Photius, Bibliotheca cod. 280, PG 104, 325-356, thum. O. Jurewicz: Focjusz, Biblioteka, t. 5: Kodeksy 249280, Warszawa 1999, 243-264. Zapisy w kalendarzu potwierdzające pamięć przynajmniej jednego rzymskiego męczennika o imieniu Nowacjan, rzucają nowe światło na nierozwiązaną ostatecznie kwestię jego męczeństwa, por. Alexander, TRE XXIV, 679).

32 Por. D. van den Eynde, L'inscription sépulcrale de Novatian, RHE 33 (1937) 792-794; K. Sordyl, Wczesnochrześcijańskie pojęcie Boga. Polemiczne aspekty teologii Nowacjana w „De Trinitate”, Kraków 2007, 48.

${ }^{33}$ Socrates, HE IV 28, PG 67, 540A, thum. S. Kazikowski: Sokrates Scholastyk, Historia Kościoła, Warszawa 1986, 376: „Tenże poniósł później śmierć męczeńską, za rządów cesarza Waleriana, który rozpętał prześladowanie chrześcijan". 


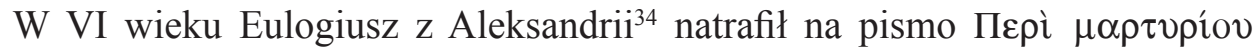

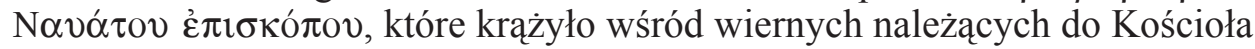
nowacjańskiego. W księdze VI swojego traktatu Przeciw Nowatowi zadał on sobie trud bezużyteczny, zanegowania legend, od których roiło się w tym piśmie. Zauważył, że nie było tam mowy o mękach znoszonych przez Nowacja$n^{35}$. Wszystko to potwierdzałoby wnioski, które pozwalają wysnuć zachowane listy pasterskie schizmatyckiego biskupa. Nowacjan mógł wyznać wiarę, nie musiał być męczennikiem (martyr) w dzisiejszym znaczeniu tego słowa.

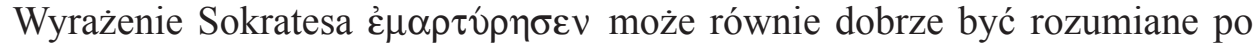
prostu jako wyznanie wiary ${ }^{36}$.

W Rzymie Nowacjan nadal kierował wspólnotą, którą zgromadził. Znamy listy pasterskie, których tytuły zachował Hieronim i które częściowo dochowały się do dziś ${ }^{37}$. Dzieła przypisane Nowacjanowi przez Hieronima to $D e$ cibis Iudaicis $^{38}$, De Trinitate ${ }^{39}$ oraz korespondencja Nowacjana ${ }^{40}$. Świadcza one o problemach, jakie miał Nowacjan, by tę wspólnotę utrzymać „mocną w Ewangelii” (,Novatianus plebi in Evangelio perstanti salutem”), jak to zaznacza w nagłówku De cibis $^{41}$. Kiedy Nowacjan pisał listy - De cibis Iudaicis,

${ }^{34}$ Eulogiusz w latach 580-607 był patriarchą Aleksandrii, zaprzyjaźnionym z Grzegorzem Wielkim. W licznych pismach walczył z nowacjanami (zachowały się tylko fragmenty), a zwłaszcza przeciw monofizytom, por. B. Altaner - A. Stuiber, Patrologia, tłum. P. Pachciarek, Warszawa 1990, 660 .

${ }^{35}$ Por. Photius, Biblioteca cod. 280, PG 104, 353, thum. Jurewicz, s. 262.

${ }^{36}$ Tak interpretuje ten fakt É. Amann, Novatien, DThC XI/1 843.

${ }^{37}$ Najbardziej kompletny wykaz owoców działalności literackiej Nowacjana dostarcza nam Hieronim w De viris illustribus 70, PL 23, 718: „Novatianus, Romanae urbis presbyter [...] scripsit De Pascha, De Sabbato, De circumcisione, De sacerdote, De oratione, De cibis Iudaicis, De instantia, De Attalo, multaque alia, et De Trinitate grande volumen, quasi epitomen operis Tertulliani faciens, quod plerique nescientes Cypriani existimant"; por. Gerolamo, Gli uomini illustri (De viris illustribus), a cura di A. Ceresa-Gastaldo, Firenze 1988, 176-178. Z tej okazałej listy udało się potwierdzić autentyczność jedynie dwóch dzieł: De cibis Iudaicis i De Trinitate. Obydwa te dzieła przeszły do historii pod nazwiskiem Tertuliana, por. C. Granado, Novaziano, La Trinidad, Fuentes Patrísticas 8, Madrid 1996, 16.

${ }^{38}$ Por. Novatianus, De cibis Iudaicis, PL 3, 981-992, lub ed. G.F. Diercks, CCL 4, 89-101.

${ }^{39}$ Por. Novatianus, De Trinitate, PL 3, 861-870, lub CCL 4, 11-78. Interesująca jest kwestia autorstwa tego traktatu i komentarz Hieronima. Omawiam te kwestie w: Sordyl, Wczesnochrześcijańskie pojęcie Boga, s. 48-55.

${ }^{40}$ Wydaje się, że Hieronim znał korespondencję Nowacjana. Prawdopodobnie chodzi tutaj o kolekcję listów pasterskich, do których należą: De cibis Iudaicis, De circumcisione, De Sabbato i być może inne małe pisma, które wspomniane są w spisie umieszczonym w De viris illustribus. Poza tym dwa listy Nowacjana zachowały się w korespondencji Cypriana: listy 30 i 36 . Nie budzi żadnej wątpliwości przypisanie autorstwa pierwszego z tych listów Nowacjanowi, bo Cyprian wspomina go imiennie jako list Nowacjana w swoim liście 55, 1-2. Autentyczność pierwszego listu pociąga za sobą autentyczność drugiego. To z pewnością to samo pióro redagowało zarówno ten pierwszy, jak i ten drugi, por. Amann, Novatien, DThC XI/1, 818.

${ }^{41}$ Por. Novatianus, De cibis Iudaicis, PL 3, 981 lub CCL 4, 89. Początek listu przypomina dwa uprzednie pisma, w których autor wyjasnia: „quid sit vera circumcisio, quid sit verum sabbatum”. 
De spectaculis ${ }^{42}$ i De bono pudicitiae ${ }^{43}$ był oddzielony od swojej wspólnoty. W listach tych znajdują się myśli, które pomagają zrozumieć, jak w praktyce powinna żyć wspólnota nowacjańska.

De cibis Iudaicis ${ }^{44}$ to list pasterski, którego autor przestrzega swoje owieczki przed pokusami przywiązywania jakiejkolwiek wagi do reguł żydowskich dotyczących żywności. Inspirując się tymi samymi pomysłami, które budują wątek w Epistola Barnabae, wykazuje, że Prawo powinno być interpretowane w sposób duchowy; to, czego zabrania, to ułomności i wady, których symbolami są zakazane zwierzęta. Nie posuwając się do stwierdzenia, jak pseudo-Barnaba, że Żydzi zrozumieli swe Prawo błędnie, autor kładzie nacisk na to, iż to Prawo, niezależnie od tego, jaki nakładało obowiązek w Starym Przymierzu, w Nowym zostało zniesione. To jednak nie znaczy, że w ramach umartwienia ciała i ascezy, chrześcijanie nie mogą odmówić sobie, w pewnych dniach, takich czy innych pokarmów. Co się zaś tyczy zwierząt złożonych w ofierze bóstwom, powinni się oni od nich powstrzymać ${ }^{45}$.

W liście De spectaculis ${ }^{46}$ Nowacjan przestrzega wspólnotę przed różnego typu niebezpieczeństwami, które wynikają z przedstawień; jest to przede wszystkim niebezpieczeństwo bałwochwalstwa oraz niemoralności. Majestatyczne spektakle natury, czy cudowne sceny z Pisma Świętego są zdecydowanie atrakcyjniejsze i zasługują według niego w oglądaniu na pierwszeństwo ${ }^{47}$.

List pasterski De bono pudicitiae ${ }^{48}$ napisany został w takich samych warunkach jak De spectaculis i De cibis. Zawiera on pochwałę czystości z kil-

Te dwa pisma, wspomniane przez Hieronima, poruszały się w tym samym porządku myślowym, jak dzieło De Pascha. Nie ulega wątpliwości, że wpisują się one w okres schizmatycki życia Nowacjana, por. Amann, Novatien, DThC XI/1 817.

${ }^{42}$ Por. Novatianus, De spectaculis, PL 4, 811-818. Prolog bardzo przypomina ten z De cibis: szczegółowe porównanie stylistyczne ujawnia wiele zbieżności z pismami autentycznymi Nowacjana. To właśnie Nowacjanowi przypisuje ten traktat wielu krytyków: A. Harnack, V. Ammundsen, W.Y. Fausset, A. d'Alès. Por. Amann, Novatien, DThC XI/1 819.

${ }^{43}$ Novatianus, De bono pudicitiae, PL 4, 851-860 lub CCL 4, 113-127.

${ }^{44}$ Por. Vogt, Novatian, LThK ${ }^{3}$ VII 939; Klein, Novatian, BBKL VI 1047-1049.

${ }^{45}$ H.J. Vogt (LThK ${ }^{3}$ VII 939) tak komentuje treść listu: w De cibis Nowacjan przedstawia zwierzęta nieczyste zakazane w Piśmie Świętym, które reprezentują złe działania ludzi $(3,12)$; to co jest zabronione to nie jedzenie ptaków drapieżnych, ale grabież $(3,20)$.

${ }^{46}$ Por. Vogt, Novatian, LThK ${ }^{3}$ VII 939; Klein, Novatian, BBKL VI 1047-1049.

${ }^{47}$ Por. Amann, Novatien, DThC XI/1 819. H.J. Vogt (Novatien, LThK ${ }^{3}$ VII, 1777-1779) natomiast zauważa, że list De spectaculis zwalcza tych, którzy chcieli usprawiedliwić zasadność teatru i ich uczestnictwa w przedstawieniach publicznych, odwołując się do argumentów pochodzących z Pisma Świętego, przytaczając epizod tańca Dawida $(3,2)$; występuje także przeciw tym, którzy chcieli pogodzić chrześcijaństwo i kulturę teatru, stan rzymski i Kościół. Wszystko to dzieje się w kontekście epoki, która poprzedza prześladowania Decjusza, za panowania Filipa Araba, który był dość przychylny wobec chrześcijan. Nowacjan usiłuje zwrócić uwagę na niemoralną zawartość spektakli pogańskich. Dla chrześcijan jedynie opowieści z Pisma Świętego są właściwe (Spect. 10, 1); zob. H.J. Vogt, Novatien, s. 1777-1779.

${ }^{48}$ Por. Vogt, Novatian, LThK ${ }^{3}$ VII 939; Klein, Novatian, BBKL VI 1047-1048. 
koma bardzo czytelnymi zapożyczeniami z De pudicitia Tertuliana, mimo iż jego temat jest inny. Nie chodzi tylko o czystość małżeńską, ale o doskonałą wstrzemięźliwość; pierwsza przybiera formę nakazu, druga jest tylko radą, ale stanowi przygotowanie do przyszłego życia (quid aliud est quam futurae vitae gloriosa meditatio). Całość kończą praktyczne rady na temat skromności i wstydliwości, które stoją na straży czystości ${ }^{49}$.

Nowacjańska wizja Kościoła, która wyłania się z jego spuścizny literackiej, jest następująca: Kościół to wspólnota proroków i męczenników, niepokalana dziewica. Ta idea Kościoła mesjanistycznego, heroicznego i pozostającego w konflikcie ze światem, jak już wspomniano, podejmowała w pewnej mierze konflikt, który przeciwstawił Hipolita i Kaliksta.

\section{ELEMENTY DOKTRYNY I STRUKTURY KOŚCIOŁA NOWACJAŃSKIEGO}

Nowacjanizm w dwóch następnych pokoleniach zrobił poważne postępy zwłaszcza na Wschodzie. W Azji Mniejszej istniały stare wspólnoty montanistyczne, które odróżniały się od Kościoła jedynie nieprzejednanym rygoryzmem. Sokrates zaznacza wyraźnie, że spośród nich Nowacjan rekrutował swoich zwolenników. Te wspólnoty, informuje, przyłączyły się do Nowacjana. Ostatecznie doszło do fuzji między należącymi do Kościoła nowacjańskiego a montanistami ${ }^{50}$.

To połączenie musiało pociągnąć za sobą kilka doprecyzowań w doktrynie sekty. Rygorystyczna doktryna montanistów uzupełniła wiele kwestii, na temat których nie wypowiadał się Nowacjan. Rygoryzm ten odrzucał drugie małżeństwo, i jeśli mielibyśmy wyciagać wnioski na podstawie złorzeczeń Tertuliana montanisty przeciw edyktowi Kaliksta, nie uznawał on rozgrzeszenia kościelnego osób, które winne były grzechu cudzołóstwa.

Część tych poglądów przeszło do Kościoła Nowacjana. Najpierw jednak zajmijmy się tym, co odnosi się do powtórnego związku małżeńskiego. Świadectwa z III wieku nie pozwalają jednoznacznie stwierdzić, czy sam Nowacjan traktował je jako niezgodne z prawem. Dopiero pod koniec IV wieku Rufin informuje, że Nowacjan (nazywa go Novat), potępił je:

${ }^{49}$ Por. Amann, Novatien, DThC XI/1 819; H.J. Vogt (Novatien, LThK ${ }^{3}$ VII, 939) zauważa, że dzieło De bono pudicitiae powstało po jego święceniach biskupich. Wspomina on w nim o swoim niemal codziennym kazaniu na temat Ewangelii $(1,1)$. Podstawowym powodem praktyki czystości jest sam Kościół, dziewica i małżonka $(2,2)$.

${ }^{50}$ Por. W.H.C. Frend, The Donatist Church, Oxford 1952, 59; zob. także: Rufinus, Expositio Symboli 39, PL 21, 376; Socrates, HE IV 28; R.J. DeSimone (Novatiens, DCA I 1780) wydarzenia przedstawia w ciagu pewnych zależności: w Azji Mniejszej (III-VII w.) stary Kościół proroczy został zastąpiony przez montanistyczny, a ten przez nowacjański. 
„Novatus lapsis paenitentiam denegando et secundas nuptias, cum forte iniri eas necessitas exegerit, condemnando" 51 .

Informacja ta nie wnosi nic nowego, gdyż przypisuje ona twórcy sekty potępienie, które było powszechne między należącymi do Kościoła nowacjańskiego w IV wieku. Epifaniusz mówi o tym na Wschodzie ${ }^{52}$ i jego świadectwo jest potwierdzone przez Sokratesa:

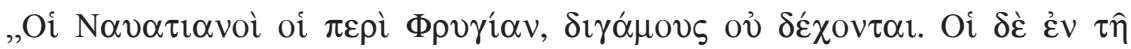

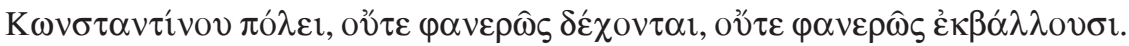

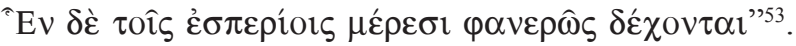

Świadectwa literackie są w zgodzie z tą uwagą Sokratesa. Źródła zachodnie nie przypisują wyznawcom Kościoła nowacjańskiego potępienia dwużeństwa (np. Filastriusz czy Pseudo-Augutyn). Tylko źródła wschodnie i te, które od nich zależą potwierdzają ten szczegół: Epifaniusz, Augustyn, autorzy De haeresibus i Praedestinatus, czy Teodoret. Zwłaszcza na terytorium, gdzie montaniści byli liczni, wyjście za mąż po raz drugi było potępione. W innych miejscach na Wschodzie wahano się, na Zachodzie zaś Kościół nowacjański dopuszczał powtórne wyjście za mąż.

Rygor dyscypliny pokutnej mógł być zaostrzony w co najmniej kilku wspólnotach. Nowacjan, jak wiadomo, dopuszczał do pokuty i pojednania tych, którzy byli winni pewnych grzechów cielesnych. Wydaje się, że później było to traktowane i u niego bardziej surowo: na pewno wpłynął na to montanizm. Teodoret relacjonuje, że wśród zwolenników nowacjanizmu nie ma mowy o pokucie:

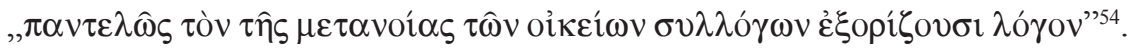

Relacja Pseudo-Augustyna na ten temat nie jest zbyt jasna. Wynika z niej, że Kościół nowacjański nie wybaczał nierządnikom. Zarzuca mu niekonsekwencję, gdyż wybaczał on zabójstwo i cudzołóstwo, które są dużo poważniejsze, niż zwykły nierząd ${ }^{55}$. Trudno jednak dokonać analizy tego tekstu, gdyż wiele informacji jest tu pomieszanych.

To co jeszcze moglibyśmy znaleźć na ten temat, to postawa, którą Sokrates przypisuje biskupowi nowacjańskiemu Nicei Asklepiadesowi. W jednej z dyskusji z Attykiem, arcybiskupem Konstantynopola (405-425), Asklepiades twierdzi, że poza faktem zaparcia się wiary, istnieją wedle Pisma także i inne grzechy śmiertelne, za które katolicy wykluczają duchownych, a oni i laików, powierzając samemu Bogu troskę o przebaczenie:

\footnotetext{
${ }^{51}$ Rufinus, Expositio Symboli 39, PL 21, 376BC.

${ }^{52}$ Por. Epiphanius, Haereses 59, 3.

${ }^{53}$ Socrates, HE V 22, PG 67, 641A.

${ }^{54}$ Theodoretus, Haereticarum fabularum compendium III 5, PG 83, 408B.

${ }^{55}$ Por. Ps-Augustinus, Quaestiones ex utroque mixtim 102: Contra Novatianum, PL 35, 2305.
} 


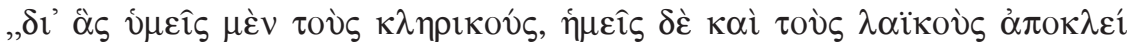

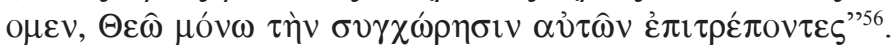

Inaczej mówiąc, Kościół nowacjański stosuje wobec wszystkich swoich członków regułę, którą katolicy odnoszą tylko do duchownych. U katolików duchowny odpowiedzialny za grzech śmiertelny jest definitywnie wykluczony ze swojej funkcji, ale nie z Kościoła. Natomiast u Nowacjan laik odpowiedzialny za te same grzechy jest definitywnie wykluczony ze wspólnoty. Ta uwaga Asklepiadesa potwierdza do pewnego stopnia wspomnianą wyżej obserwację Teodoreta. To samo wrażenie mamy po przeczytaniu listów Pacjana do Symproniana ${ }^{57}$.

Powyższy rygoryzm w dyscyplinie pokutnej zakłada, jak powiedzieliśmy, określoną koncepcję Kościoła i teorię władzy kluczy, która znacznie różniła się od tej, którą sprecyzował katolicyzm. Poza tym jednak nie zauważamy rozbieżności dogmatycznych pomiędzy nowacjanizmem i katolicyzmem.

Kwestia ustalenia daty Wielkanocy doprowadziła jednak do rozdziału między wieloma wspólnotami nowacjańskimi a Kościołem. Montaniści z Azji Mniejszej uzgodnili, że aby obliczyć datę Wielkanocy dostosują się do obliczeń żydowskich. Nowacjanie z Frygii poszli ich śladem i ostatecznie przyjęli ich koncepcję. W czasach cesarza Walensa (364-378), synod zwołany w Pazos $^{58}$ zdecydował, że przyłączą się do obliczeń żydowskich determinujących datę Wielkanocy:

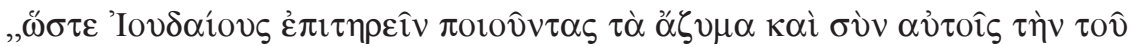

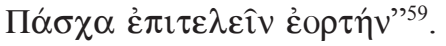

$\mathrm{Na}$ Zachodzie zwolennicy nowacjanizmu nie oddalali się od zwyczaju tradycyjnego, podobnie na Wschodzie, mimo iż niektórzy podjęli wysiłek rozprzestrzenienia stanowiska frygijskiego. Nie wydaje się jednak, by wyszło ono daleko poza granice kraju swojego pochodzenia. W 384 roku Marcjan objął po Ageliuszu przewodzenie wspólnocie nowacjańskiej w Konstantynopolu i był zmuszony stawić czoło schizmie Sabbatiosa, który przejął w kwestii

${ }^{56}$ Socrates, HE VII 25, PG 67, 796D, thum. S. Kazikowski, s. 533: „Poza składaniem ofiar pogańskich, jest jeszcze wiele innych, jak to uczy Pismo Święte, grzechów śmiertelnych, dla których wy duchownych wykluczacie, a my - także i świeckich, samemu Bogu tylko zostawiając ich odpuszczanie".

${ }^{57}$ Por. L. Wohleb, Bischof Pacianus von Barcelona und sein Gegner, der Novatianer Sympronianus. (Mit einer Sammlung der Fragmente Sympronians), Gesammelte Aufsätze zur Kulturgeschichte Spaniens, Bd. 2, Münster 1930, 25-35; C. Granado, Introduction. Simpronien, correspondant de Pacien, SCh 410, 45-48.

${ }^{58} \mathrm{~W}$ czasach, kiedy biskupem nowacjan był Agelius, ale podczas jego nieobecności, por. Mattei, Novaziani, NDPAC II 3552-3556.

${ }^{59}$ Socrates, HE IV 28, PG 67, 540B, thum. S. Kazikowski, s. 376: „mniej znani biskupi nowacjańscy we Frygii zwoławszy synod w osadzie Pazos [...] ogłosili postanowienie, że trzeba się trzymać terminu, w którym żydzi obchodzą święto Przaśników, i urządzać święto Paschy w tym samym czasie, co i oni”. 
daty wielkanocnej stanowisko judaistyczne, podobnie jak to uczynili kilka lat wcześniej biskupi nowacjańscy we Frygii. Chciano położyć kres tym kłótniom, deklarując poprzez synod zgromadzony niedaleko Helenopolis w Bi-

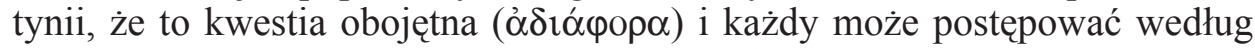
własnych przekonan ${ }^{60}$. Stronnictwo sabatian ${ }^{61}$ kontynuowało jednak swoją tradycję w separacji.

Relacje Sokratesa na temat wewnętrznych sporów Kościoła nowacjańskiego pozwalają nam dostrzec kilka cech jego wewnętrznej struktury. Nie wydaje się ona różnić od tego, co w tamtych czasach miało miejsce w Kościele katolickim. Odnajdujemy tam: biskupów, prezbiterów, diakonów, czy synody. Przyznaje się także pewną wyższość nominacjom do ważniejszych miast. Jeśli chodzi o synod frygijski w Pazos, Sokrates wyraźnie zaznacza, że nieobecność na tym spotkaniu biskupów Konstantynopola, Nikomedii i Kutahii (współcz. Kutahya) była celowa. Chodziło o to, by złagodzić ważność podjętych decyzji:

„ن்

Sakramenty u nowacjan były takie same, jak w Kościele katolickim, jednak według Teodoreta Kościół nowacjański nie praktykował nałożenia olejów po chrzcie:

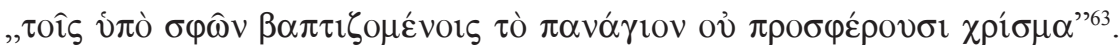

Podobną myśl odnajdujemy u Pacjana:

„Vestrae plebi unde Spiritum, quam non consignat unctus sacerdotos?”64.

Między katolikami, przynajmniej na Wschodzie, przyjęto, że należy namaszczać krzyżmem tych, którzy nawrócili się z Kościoła nowacjańskiego. Również w Kościele nowacjańskim, i to od samego początku, udzielano powtórnego chrztu katolikom, którzy wstępowali do tej sekty ${ }^{65}$. Według Eulogiusza nowacjanie w Aleksandrii odrzucali kult relikwii ${ }^{66}$.

\section{SOBÓR NICEJSKI WOBEC KOŚCIOŁA NOWACJAŃSKIEGO}

Pod koniec III wieku, jak zasygnalizowano, nastapiło umocnienie Kościoła nowacjańskiego. Nie posiadamy informacji na temat tego, jak Kościół ten

\footnotetext{
${ }^{60}$ Socrates, HE V 21, PG 67, 624.

${ }^{61}$ Od Sabbatiosa, przywódcy judeochrześcijańskiej grupy wiernych obchodzących Paschę razem z Żydami, a nie w niedzielę po pierwszej pełni wiosennej.

${ }^{62}$ Socrates, HE IV 28, PG 67, 541A.

${ }^{63}$ Theodoretus, Haereticarum fabularum compendium III 5, PG 83, 408B.

${ }^{64}$ Pacianus, Epistula 3, 3, 2, PL 13, 1065A, thum. K. Bardski, BOK 12, Kraków 2000, 80: „Skąd lud wasz, który nie uznaje namaszczonego biskupa, otrzymał Ducha Świętego?”.

${ }^{65}$ Por. Amann, Novatien, DThC XI/1 845. R.J. DeSimone (Novatiens, DCA I 1780) przekazuje, że uczyniły to Kościoły nowacjańskie Afryki.

${ }^{66}$ Por. Mattei, Novaziani, NDPAC II 3555.
} 
zachowywał się w czasie wielkich prześladowań. Kiedy chrześcijanie uzyskali pokój, Kościół nowacjański jako rywal wykorzystał to, ale nie uczestniczył w działaniach na korzyść chrześcijan, którym wkrótce władza cesarska przyznała pokój.

Sokrates $^{67}$, a później Sozomen ${ }^{68}$, mówią wyraźnie, że biskup nowacjański Acesius, który bez wątpienia był biskupem stolicy, został wezwany przez Konstantyna ${ }^{69}$ na sobór w Nicei. Zapytany przez cesarza odpowiedział, że nie widział żadnego problemu, by podpisać soborową formułę wiary ${ }^{70} \mathrm{i}$ reguły dotyczące Wielkanocy ${ }^{71}$. Wyjaśnił jednak cesarzowi, że między jego Kościołem a Kościołem katolickim istnieje ważny spór, dotyczący kwestii pokutnej. H. Valois usiłuje podważyć takie ujęcie, które jest jednak bardzo prawdopodobne $^{72}$. Można zrozumieć to, że cesarz chciał przy okazji soboru zatrzeć wrażenie separacji religijnej, która według niego nie miała już racji bytu.

Sobór Nicejski ${ }^{73}$ starał się przywrócić nowacjan do jedności z Kościołem ka-

${ }^{67}$ Por. Socrates, HE I 10, PG 67, 100-101.

${ }^{68}$ Sozomenus, HE I 22, PG 67, 924-925.

${ }^{69}$ Mamy w starożytności synody dwojakiego rodzaju: prowincjonalne zwoływane przez metropolitę, zwykle dwa razy w roku, oraz „cesarskie” (że tak pozwolę je sobie nazwać), zwoływane nieregularnie, w sprawach, które imperator uważał za ważne i odbywały się z udziałem takich biskupów i innych ekspertów, jakich sam zaprosił. Te ostatnie mogły mieć w zamierzeniu cesarza zasięg terytorialny albo uniwersalny. Nie znaczyło to, że zapraszano wszystkich biskupów, ale że brali w nich udział przedstawiciele Wschodu i Zachodu. Te drugie synody przyjęło się nazywać soborami powszechnymi, por. H. Pietras, Synodalność w kościele starożytnym, w: Dokumenty Soborów Powszechnych (= DSP), t. 1: 325-787, ŹMT 24, Kraków 2002, 10.

${ }^{70}$ Ustalono wyznanie wiary, które wydaje się być owocem kompromisu pomiędzy tymi, którym bardziej zależało na potępieniu Ariusza negującego odwieczność Syna Bożego, a tymi, którzy bardziej obawiali się sformułowań przypominających twierdzenia Pawła z Samosaty. Kluczowe dla późniejszych dyskusji trynitarnych pojęcie współistotności Ojca i Syna, podobno zaproponowane przez samego cesarza, spotkało się z nader niechętnym przyjęciem, przede wszystkim z powodu niewystepowania tego terminu w Piśmie Świętym oraz z powodu materialnych skojarzeń, jakie budziło. Dopiero specjalne orzeczenie o znaczeniu czysto duchowym tego terminu skłoniło do podpisania wszystkich biskupów, z wyjątkiem dwóch, por. H. Pietras, Wprowadzenie. Sobór Nicejski I (325), DSP 1, 22.

${ }^{71}$ Por. Concilium Nicaenum I can. 20; Epistula Concilii Nicaeni ad Aegyptios 12, thum. T. Wnętrzak, DSP 1, 47: „Ogłaszamy wam dobrą nowinę o jedności, jaka zapadła co do Świętej Paschy. Na wasze prośby ustalono jeden, odpowiedni czas. Przeto wszyscy bracia ze Wschodu, którzy niegdyś świętowali Wielkanoc z Żydami, będą ją obchodzić z Rzymianami i z nami oraz z tymi wszystkimi, którzy od dawnych czasów obchodzili Wielkanoc w tym samym czasie, co my”.

${ }^{72}$ Por. Amann, Novatien, DThC XI/1 846.

${ }^{73}$ Zgromadzenie biskupów w Nicei na zaproszenie cesarza Konstantyna Wielkiego zostało uznane za I Sobór Powszechny dopiero na Soborze Efeskim w 431 roku, pierwszym, który miał świadomość własnej powszechności. Mimo wielowiekowych studiów na ten temat, daleko jeszcze do ustalenia rzeczywistych powodów jego zwołania i przebiegu obrad. Wiadomości o nim czerpiemy od Euzebiusza z Cezarei (Vita Constantini), Atanazego (De decretis Nicaenae Synodi), z Historii Kościoła Rufina, oraz Historii Kościelnych Sokratesa Scholastyka, Sozomena, Teodoreta i Filostorgiusza, por. Pietras, Wprowadzenie. Sobór Nicejski I (325) oraz bibliografia, DSP 1, 21-23. Ponadto 
tolickim, przyjmując wobec nich postawę umiarkowaną ${ }^{74} ; \mathrm{w} 8$. kanonie przedstawił jednak „,czystym”, powracającym do Kościoła pewne warunki łaski ${ }^{75}$ :

„W sprawie tych, którzy nazywają samych siebie «katharoi», [to znaczy «czystymi»], święty i wielki sobór postanowił, że jeśli chcą powrócić do powszechnego i apostolskiego Kościoła, muszą otrzymać nałożenie rąk, a będą mogli pozostać w gronie duchownych. Konieczne jest jednak, przede wszystkim, aby oni przyobiecali na piśmie, że zgadzają się i będą posłuszni nauczaniu Kościoła powszechnego. Następnie, że pozostaną we wspólnocie z tymi, którzy dwa razy zawarli małżeństwo oraz z tymi, którzy upadli w czasie prześladowań, a którym został wyznaczony czas na odbycie pokuty i stosowna pora, aby uznali swe posłuszeństwo we wszystkim nauczaniu powszechnego i apostolskiego Kościoła. Więc jeżeli w niektórych wioskach i miastach znajdują się duchowni tylko z ich grupy, należy ich pozostawić w gronie duchowieństwa i na dotychczasowym stanowisku. Gdy zaś przybędzie któryś z «czystych» tam, gdzie jest już biskup Kościoła katolickiego lub prezbiter, to jest oczywiste, że biskup tego Kościoła zachowa swe biskupie stanowisko, zaś ten, którego nazywali biskupem owi nazywający siebie «czystymi», będzie miał prawo do godności prezbitera, chyba, że biskup uzna za właściwe zostawić mu jego godność. Jeśli zaś nie będzie tego chciał, niech da mu miejsce chorepiskopa albo prezbitera, aby było wiadomo, że nadal rzeczywiście należy do kleru, lecz aby nie było dwóch biskupów w jednym mieście"77.

Duchowni pozostaliby w duchowieństwie poprzez nałożenie rąk i jawne wyrzeczenie się rygorystycznych doktryn sekty, dotyczących powtórnego małżeństwa i lapsi. W ośrodkach, które w całości były nowacjańskie, gdzie nie było duchowieństwa katolickiego, duchowni pojednani mogli zachować swój

ważną pomoc stanowi tu książka ks. Marka Starowieyskiego: Sobory Kościoła niepodzielonego, Tarnów 1994: odnajdujemy w niej opis ośmiu pierwszych soborów uznanych za powszechne, bibliografię oraz wstępny rozdział o Kościele czasów przedpoborowych, z powstającą wówczas instytucją synodów.

${ }^{74}$ Na soborze w Nicei Kościół nowacjański zaakceptował homoousios (Socrates, HE I 10; V 10). Ojcowie soborowi wymagali od nich wyznania wiary, wyrzeczenia się błędów, oraz nałożenia dłoni, ale nie nowego chrztu (kanon 8), por. DeSimone, Novatiens, DCA I 1780.

${ }^{75}$ Por. Canones Apostolorum 46-47; Concilium Ancyranum (314) can. 13; Concilium Neocaesariensem can. 14; Concilium Nicaenum I can. 8, DSP 1, 33, n. 13: „ «Czyści» tworzyli ugrupowania radykalne, odgradzające się od innych, których uważali za niegodnych przynależności , czy to z powodu zawarcia drugiego małżeństwa, po śmierci pierwszego współmałżonka, czy z powodu załamania się w czasie prześladowań, czy choćby tylko ucieczki przed prześladowcami. Należeli do nich na przykład montaniści, donatyści czy nowacjanie".

${ }^{76}$ Concilium Nicaenum I can. 8, DSP 1, 32-35. O kwestii powrotu heretyków i schizmatyków do Kościoła, podjętej na tym soborze, tak pisze ks. M. Starowieyski (Sobory Kościoła niepodzielonego, s. 29): „Zasadniczo dzielą się oni na dwie grupy: tych, którzy ważnie otrzymali chrzest (np. nowacjanie czy egipscy melecjanie) - im należy tylko nałożyć ręce na głowę na znak pokuty, oraz tych, którzy otrzymali go nieważnie ze względu na błędy trynitarne (np. zwolennicy Pawła z Samomaty) - ci mają otrzymać go na nowo". 
stopień i funkcje. Tam zaś, gdzie byłby już biskup katolicki, biskup nowacjański pełniłby tylko funkcje kapłańskie, ale biskup katolicki mógłby mu nadać honorowy tytuł biskupa lub chorepiskopa ${ }^{77}$. To rozporządzenie zakłada, że kapłani i diakoni, przybyli z tamtego Kościoła zajęliby miejsce między ich katolickimi kolegami.

Nowacjańska wizja Kościoła pojawiła się w momencie, który sprzyjał jej dalszemu rozwojowi. Kościół ucierpiał w czasie prześladowań, ponadto pojawiły się protesty niektórych chrześcijan wobec możliwości pojednania lapsi. Istotną rolę w rozprzestrzenianiu się Kościoła nowacjańskiego spełniła również doktryna, dotycząca niemożliwości odpuszczania pewnych grzechów. Połączenie się na Wschodzie wiernych należących do Kościoła nowacjańskiego i montanistów przyczyniło się do precyzacji zasad w doktrynie sekty. Odnośnie powtórnego związku małżeńskiego, świadectwa z III wieku nie pozwalają jednoznacznie stwierdzić, czy sam antypapież traktował je jako niezgodne z prawem.

Nowacjan dopuszczał do pokuty i pojednania tych, którzy byli winni pewnych grzechów cielesnych. Wydaje się, że w okresie późniejszym wykroczenia tego typu traktowane były bardziej surowo; na pewno wpłynął na to montanizm. Ten rygoryzm w dyscyplinie pokutnej zakładał określoną koncepcję Kościoła i władzy kluczy, która znacznie różniła się od tej, którą sprecyzował katolicyzm. Poza tym jednak nie zauważamy rozbieżności dogmatycznych pomiędzy nowacjanizmem i katolicyzmem. Kwestia ustalenia daty Wielkanocy doprowadziła natomiast do rozdziału między wieloma wspólnotami nowacjańskimi a Kościołem.

Relacje Sokratesa na temat wewnętrznych sporów Kościoła nowacjańskiego pozwalają nam dostrzec kilka cech jego wewnętrznej struktury. Nie wydaje się ona różnić od tego co w tamtych czasach miało miejsce w Kościele katolickim. Odnajdujemy w niej biskupów, księży, diakonów, synody; przyznaje się u nich także pewną wyższość nominacjom do ważniejszych miast.

Sakramenty u nowacjan były takie same jak w Kościele katolickim, jednak według Teodoreta Kościół nowacjański nie praktykował nałożenia olejów po chrzcie; podobną informację odnajdujemy także u Pacjana. Między katolikami, przynajmniej na Wschodzie, przyjęto, że należy namaszczać krzyżmem tych, którzy nawrócili się z Kościoła nowacjańskiego. Również we wspólnotach nowacjańskich, i to od samego początku, udzielano powtórnego chrztu katolikom, którzy wstępowali do tej sekty. Według Eulogiusza, nowacjanie w Aleksandrii odrzucali kult relikwii.

${ }^{77}$ Chorepiskop - dosłownie «biskup wiejski», był odpowiedzialny za jakiś Kościół na peryferiach metropolii i podlegał biskupowi miasta, por. Concilium Nicaenum can. 8; F. Gillman, Das Institut der Chobischöfe im Orient, München 1903; A Di Berardino, Corepiscopo, DPAC I 780-781. 
Sobór Nicejski starał się przywrócić nowacjan do jedności z Kościołem katolickim, przyjmując wobec nich postawę umiarkowaną. Sobór ten w kanonie 8. przedstawił „czystym”, powracającym do Kościoła, pewne warunki łaski. Sobór Trydencki widział natomiast w potępieniu nowacjan dowód na prawdziwą naukę Ojców o pokucie.

\section{AN ATTEMPT TO RECONSTRUCT THE DOCTRINE AND STRUCTURE OF NOVATIAN CHURCH}

\section{(Summary)}

The Novatian vision of the Church appeared in the moment which was favourable for its further development. Not only did the Church suffer persecution, but also some Christians protested against the possibility of reconciliation lapsi. What is more, the doctrine concerning the impossibility to forgive certain sins had a significant role in spreading of Novatian Church. Merging the congregation belonging to Novatian Church and Montanists in the East contributed to specifying the doctrine of the sect. With reference to a repeat marriage, the testimonies from III century do not allow to state explicitly if the pope himself treated them as illegal.

Novatian allowed for penance and reconciliation of those who were guilty of certain carnal sins. It seems that later such violations were treated more severely. Montanism surely had an influence on it. Such rigorism in penitential discipline assumed a definite concept of Church and the power of the keys, which differed significantly from the one Catholicism set down. Apart from this, however, dogmatic divergences between Novatianism and Catholicism are not to be observed. But, the question of determining the date of Easter led to the separation between a lot of Novatian communities and the Church.

Socrates' accounts of Novatian Church internal disputes let us discern a few features of its inner structure. It does not seem to differ from that of Catholic Church. There are bishops, priests, deacons, synods. Furthermore, episcopal appointments to more important cities are considered to be superior.

The sacraments in Novatian Church were the same as in Catholic Church, however, according to Teodoret, Novatian Church did not practice anointing a person with holy oils after baptism. A similar opinion can be found in Pacian's texts. It was accepted among Catholics, at least in the East, that those who converted from Novatian Church should be anointed. In Novatian communities, from the outset, Catholics, who joined this sect, were baptized for the second time. According to Eulogius, Novatians in Alexandria rejected the cult of relics.

The council in Nice tried to restore Novatians to the unity with Catholic Church, adopting a restrained attitude towards them. The council in cannon 8 presents the "pure" returning to Church with the conditions of grace. The Trident Council, however, saw in condemning Novatians proof of true Fathers' teaching about penance. 